\author{
Matthieu Schmidt \\ Elie Zogheib \\ Hadrien Rozé \\ Xavier Repesse \\ Guillaume Lebreton \\ Charles-Edouard Luyt \\ Jean-Louis Trouillet \\ Nicolas Bréchot \\ Ania Nieszkowska \\ Hervé Dupont \\ Alexandre Ouattara \\ Pascal Leprince \\ Jean Chastre \\ Alain Combes
}

Received: 1 June 2013

Accepted: 19 July 2013

Published online: 2 August 2013

(C) Springer-Verlag Berlin Heidelberg and

ESICM 2013

Electronic supplementary material

The online version of this article (doi:10.1007/s00134-013-3037-2) contains

supplementary material, which is available to authorized users.

M. Schmidt - X. Repesse - C.-E. Luyt .

J.-L. Trouillet · N. Bréchot .

A. Nieszkowska · J. Chastre

A. Combes ( $)$

Medical-Surgical Intensive Care Unit,

iCAN, Institute of Cardiometabolism and

Nutrition, Service de Réanimation

Médicale, Groupe Hôpital de la Pitié-

Salpêtrière, Assistance Publique-Hôpitaux

de Paris, Université Pierre et Marie Curie,

Paris 6, 47, bd de l'Hôpital, 75651 Paris

CEDEX 13, France

e-mail: alain.combes@psl.aphp.fr

Tel.: +33-1-42163816

Fax: +33-1-42163817

E. Zogheib - H. Dupont

Anesthesiology and Critical Care Medicine Department, Amiens University Hospital, INSERM U-1088, Université de Picardie Jules Verne, 80054 Amiens CEDEX, France

H. Rozé · A. Ouattara

Department of Anesthesia and Critical Care II, CHU de Bordeaux, Université de Bordeaux, Adaptation cardiovasculaire à l'ischémie, U1034, 33604 Pessac CEDEX, France

\section{The PRESERVE mortality risk score and analysis of long-term outcomes after extracorporeal membrane oxygenation for severe acute respiratory distress syndrome}

G. Lebreton · P. Leprince Cardiac Surgery Department, iCAN, Institute of Cardiometabolism and Nutrition, Hôpital de la Pitié-Salpêtrière, Assistance Publique-Hôpitaux de Paris, Université Pierre et Marie Curie, Paris 6, 47, bd de l'Hôpital, 75651 Paris CEDEX 13, France

\section{Abstract Purpose: This study} was designed to identify factors associated with death by 6 months post-intensive care unit (ICU) discharge and to develop a practical mortality risk score for extracorporeal membrane oxygenation (ECMO)treated acute respiratory distress syndrome (ARDS) patients. We also assessed long-term survivors' healthrelated quality of life (HRQL), respiratory symptoms, and anxiety, depression and post-traumatic stress disorder (PTSD) frequencies. Methods: Data from 140 ECMO-treated ARDS patients admitted to three French ICUs (2008-2012) were analyzed. ICU survivors contacted $>6$ months post-ICU discharge were assessed for HRQL, psychological and PTSD status. Results: Main ARDS etiologies were bacterial (45\%), influenza $\mathrm{A}\left[\mathrm{H}_{1} \mathrm{~N}_{1}\right](26 \%)$ and post-operative (17\%) pneumonias. Six months post-ICU discharge, $84(60 \%)$ patients were still alive. Based on multivariable logistic regression analysis, the PRESERVE (PRedicting dEath for SEvere ARDS on VV-ECMO) score (0-14 points) was constructed with eight preECMO parameters, i.e. age, body mass index, immunocompromised status, prone positioning, days of mechanical ventilation, sepsis-related organ failure assessment, plateau pressure andpositive end-expiratory pressure. Six-month post-ECMO initiation cumulative probabilities of survival were $97,79,54$ and $16 \%$ for PRESERVE classes 0-2, 3-4, 5-6 and $\geq 7(p<0.001)$, respectively. HRQL evaluation in $80 \%$ of the 6-month survivors revealed satisfactory mental health but persistent physical and emotional-related difficulties, with anxiety, depression or PTSD symptoms reported, by 34,25 or $16 \%$, respectively. Conclusions: The PRESERVE score might help ICU physicians select appropriate candidates for ECMO among severe ARDS patients. Future studies should also focus on physical and psychosocial rehabilitation that could lead to improved HRQL in this population.

Keywords Extracorporeal membrane oxygenation . Acute respiratory distress syndrome . Outcome assessment .

Long-term quality of life 


\section{Introduction}

Patients who develop the most severe forms of acute respiratory distress syndrome (ARDS) still have mortality rates exceeding $50 \%[1]$ and survivors have persistently impaired physical, functional and psychological components of health-related quality of life (HRQL), despite optimal supportive care provided during their intensive care unit (ICU) stays [2-6]. In this setting, extracorporeal membrane oxygenation (ECMO) has been proposed as a possible therapeutic option allowing ultraprotective mechanical ventilation (MV) and potentially less ventilator-induced lung damage [7-9]. Indeed, major technological improvements in ECMO machines [7, 8, 10,11], the conventional ventilation or ECMO for severe adult respiratory failure (CESAR) trial's positive results [9] and recourse to ECMO-rescue therapy for the most severe cases of $\mathrm{A}\left(\mathrm{H}_{1} \mathrm{~N}_{1}\right)$ influenza-induced ARDS that failed on conventional ventilation [12-14] have renewed recent interest in this technique.

Because extended use of ECMO, which requires highly specialized staff and equipment, may increase resource utilization and hospitals costs, early identification of mortality risk factors and detailed analyses of long-term outcomes of survivors are needed. However, to date, studies reporting factors associated with death for severe ARDS adult patients who received ECMO are scarce $[15,16]$, did not evaluate the impact of pre-ECMO MV settings or rescue maneuvers such as prone positioning [17] and are based on data collected before the development of modern ECMO devices and the widespread adoption of protective MV recommendations based on ARDSnet studies [18]. Additionally, only a few studies based on limited numbers of patients evaluated longterm outcomes in ECMO-treated ARDS survivors [9, 1921]. Therefore, this study was designed to identify factors associated with death by 6 months post-ICU discharge for ARDS patients treated with the latest generation ECMO systems and to assess long-term survivors' HRQLand psycho-emotional sequelae.

\section{Patients and methods}

Study design and objectives

The primary objective of this multicenter retrospective study, which included all consecutive severe ARDS patients who received ECMO in three adult ICUs in French university hospitals between May 2008 and January 2012, was to identify factors associated with death by 6 months following ICU discharge and to derive a practical mortality risk score that might help ICU physicians select appropriate candidates for ECMO. Long-term survivors' HRQL, respiratory symptoms, and anxiety, depression and post-traumatic stress disorder (PTSD) frequencies were also evaluated.
Patients

The decision to initiate ECMO was based on the following: persistent hypoxemia, defined as $\mathrm{PaO}_{2} / \mathrm{FiO}_{2}$ $<80 \mathrm{mmHg}$ with $\mathrm{FiO}_{2} \geq 80 \%$ for $>6 \mathrm{~h}$, despite optimization of MV (Vt set at $6 \mathrm{~mL} / \mathrm{kg}$ and trial of positive endexpiratory pressure $[P E E P] \geq 10 \mathrm{~cm} \mathrm{H}_{2} \mathrm{O}$ ), and despite possible recourse to adjunctive therapies (NO, prone position, HFO ventilation) and/or $\mathrm{pH}<7.25$ (with $\mathrm{PaCO}_{2} \geq 60 \mathrm{mmHg}$ ) for $>6 \mathrm{~h}$ resulting from MV settings adjusted to keep plateau pressure (Pplat) $\leq 32 \mathrm{~cm} \mathrm{H}_{2} \mathrm{O}$ [22]. Exclusion criteria for ECMO were patients with chronic respiratory insufficiency treated with oxygen therapy and/or long-term respiratory assistance, malignancies with fatal prognosis within 5 years, moribund patients or those with irreversible neurological pathologies and decisions to limit therapeutic interventions. In accordance with the ethical standards of our hospital's Institutional Review Board, obtaining informed consent for demographic, physiological and hospital-outcome data analyses was not necessary, because this retrospective observational study did not modify existing diagnostic or therapeutic strategies. Additional information on patients' data and descriptions of ECMO management [23] are detailed in theelectronic supplementary material (ESM).

\section{Outcome variables}

We recorded ICU events, including cardiac arrest, bleeding, infections [24] and ECMO-related hemolysis, durations of ECMO and MV support, ICU and hospital lengths of stay, and mortality. Patients discharged from the ICU were contacted $>6$ months later and oral consent was obtained to complete long-term HRQL, pulmonary symptoms and psychological assessment questionnaires. The same investigators (MS, EZ, HR) interviewed all patients, asking the questions in the questionnaire in the same order by telephone.

Long-term HRQL was assessed with the French version of the Medical Outcome Short-Form (SF)-36 [25-27] and our patients' SF-36 scores were compared with ageand sex-matched French control subjects [27]. Pulmonary symptoms were evaluated with the St George's Respiratory Questionnaire (SGRQ) [28]. Anxiety and depression symptoms were assessed with the Hospital Anxiety and Depression (HAD) Scale [29], with respective HAD-A and HAD-D subscale scores $\geq 8 / 21$ considered clinically significant [29]. PTSD-related symptoms were assessed with the Impact of Event Scale (IES) [30], and patients with a total IES score $\geq 30 / 75$ points were considered at high risk for PTSD. Lastly, activities of daily living (ADL) were evaluated with the basic ADL and instrumental ADL (IADL) scales [31, 32]. To put questionnaire scores of our ARDS ECMO-treated patients into perspective, we searched the literature for other studies reporting long-term 
outcomes of patients who survived ARDS or other severe diseases treated in the ICU. Details on outcome-variable evaluations and on series selected as comparators $[3,4,9$, $19,20,25,33-39]$ are provided in the ESM.

\section{Statistical analyses}

Continuous variables were compared with Student's $t$ test or the Mann-Whitney $U$ test, as appropriate. For comparisons of patients' mean SF-36 scores with those of their age- and sex-matched control subjects, paired $t$ tests or Wilcoxon tests were used. To examine the effects of patients' clinical characteristics associated in the univariable analysis with death by 6 months post-ICU discharge, a logistic regression model was used to test each characteristic. Thereafter, multiple logistic regression using backward stepwise variable elimination (with the variable exit threshold set at $p>0.05$ ) was applied. Factors achieving $p \leq 0.20$ in our univariable analysis were entered into the model. Prone positioning was forced in the model because a study recently showed that it was associated with better outcomes in moderate to severe ARDS patients [40]. All potential explanatory variables included in the multivariable analyses were subjected to a correlation matrix for analysis of collinearity. Variables with association among each other were not included in the multivariable model. Then, to derive a simple and practical score to predict survival, i.e. the PRESERVE (PRedicting dEath for SEvere ARDS on VV-ECMO) score, we re-ran the final logistic regression model with continuous variables transformed into categorical variables (by defining best thresholds after analyzing mortality in each quartile of the corresponding variable). PRESERVE subscores for each factor were the $\beta$-coefficients of the logistic regression model divided with the smallest coefficient of the model and rounded to the nearest integers. The discriminative performance of the PRESERVE score was evaluated with receiver operating characteristics (ROC) curve and quantified by calculating the area under the curve and $95 \%$ CI. Lastly, KaplanMeier survival analysis was used to estimate the probability of survival after ECMO initiation among quartiles of the PRESERVE score. $P<0.05$ defined statistical significance. Analyses were computed with StatView v5.0 (SAS Institute Inc., Cary, NC, USA) and SPSS 11.0 (SPSS Inc., Chicago, IL, USA) software.

\section{Results}

Study population

During the study period, 140 patients (Fig. 1) with refractory ARDS [age 44 (30-56) years, $61 \%$ male] received ECMO in three French university ICUs (Amiens, $n=33$; Bordeaux, $n=23$; Paris, $n=84$ ). Patients' characteristics at ICU admission are given in Table 1. Infectious diseases were the leading causes of ARDS: $45 \%$ bacterial and $26 \% \mathrm{~A}\left(\mathrm{H}_{1} \mathrm{~N}_{1}\right)$ influenza pneumonias. Before ECMO implantation, median $\mathrm{PaO}_{2} /$ $\mathrm{FiO}_{2}$ was 53 (43-60). Median time between intubation and ECMO cannulation was 5 (1-11) days. Notably, refractory hypoxemia occurred despite the recourse to prone positioning for almost two-thirds of our patients (Table 2). Venovenous (VV) ECMO was used in $95 \%$ of patients, most frequently with femoral-jugular cannulation $(n=121)$; six patients received Avalon cannulae and six had cannulae inserted in both femoral veins. Venoarterial (VA)-ECMO was used for the seven patients whose ARDS was associated with severe cardiovascular dysfunction [41].

ECMO support allowed 'ultraprotective' MV settings: Pplat was decreased from $32(30-35)$ to $24(22-26) \mathrm{cm}$ $\mathrm{H}_{2} \mathrm{O}$, tidal volume from $5.9(5.2-6.7)$ to $2.8(2.0-4.4) \mathrm{mL} /$ $\mathrm{kg}$, while PEEP remained stable. Blood gases normalized within $6 \mathrm{~h}$ of ECMO initiation (Table 2; Table E1[see ESM]).

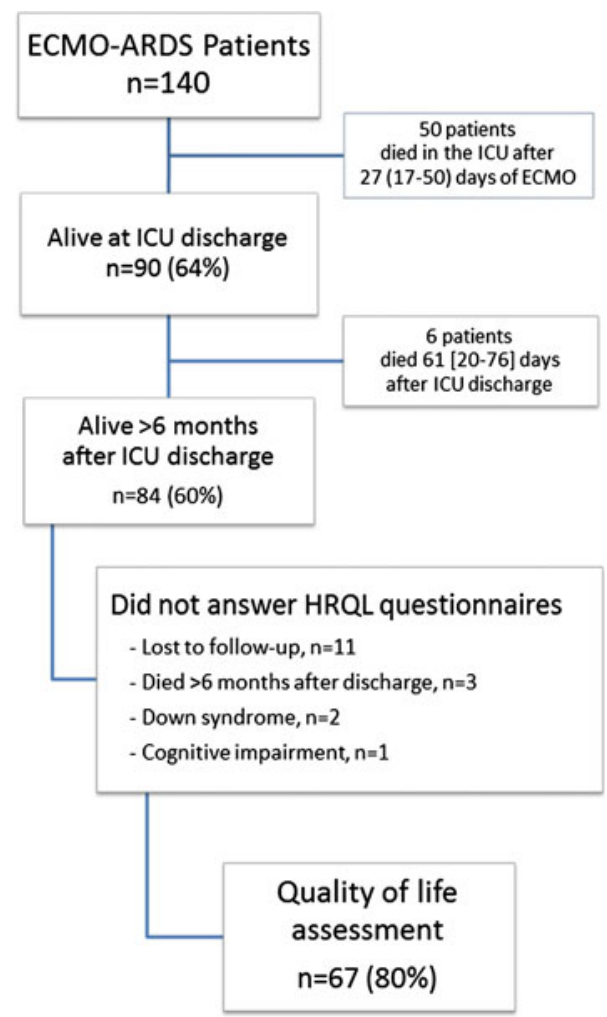

Fig. 1 Study flowchart. Durations are median (interquartile range). $A R D S$ acute respiratory disease syndrome, ECMO extracorporeal membrane oxygenation, $H R Q L$ health-related quality of life, $I C U$ intensive care unit 
Table 1 Clinical characteristics of ECMO-treated ARDS patients according to survival status 6 months post-ICU discharge

\begin{tabular}{|c|c|c|c|c|}
\hline \multirow[t]{2}{*}{ Characteristic } & \multirow{2}{*}{$\begin{array}{l}\text { All patients } \\
(n=140)\end{array}$} & \multicolumn{2}{|c|}{ Status at 6 months post-ICU } & \multirow[t]{2}{*}{$p$-Value } \\
\hline & & $\begin{array}{l}\text { Alive } \\
(n=84)\end{array}$ & $\begin{array}{l}\text { Dead } \\
(n=56)\end{array}$ & \\
\hline Age, years & $44(30-56)$ & $37(28-47)$ & $53(44-60)$ & 0.0001 \\
\hline Men & $86(61)$ & $46(55)$ & $40(71)$ & 0.04 \\
\hline Body mass index, $\mathrm{kg} / \mathrm{m}^{2}$ & $27(24-32)$ & $29(24-36)$ & $26(24-31)$ & 0.04 \\
\hline Charlson score & $1(0-2)$ & $1(0-2)$ & $2(1-3)$ & 0.0001 \\
\hline McCabe and Jackson score $\geq 2$ & $23(16)$ & $6(7)$ & $17(30)$ & 0.0004 \\
\hline SAPS II & $59(49-71)$ & $57(47-68)$ & $64(55-74)$ & 0.04 \\
\hline SOFA score & $12(10-15)$ & $12(10-15)$ & $13(11-15)$ & 0.13 \\
\hline Chronic lung disease & $21(15)$ & $11(13)$ & $10(18)$ & 0.59 \\
\hline Pregnant or postpartum & $7(5)$ & $7(8)$ & 0 & 0.02 \\
\hline Diabetes mellitus & $14(10)$ & $5(6)$ & $9(16)$ & 0.05 \\
\hline Renal insufficiency & $9(6)$ & $6(7)$ & $3(5)$ & 0.67 \\
\hline Immunocompromised $^{\mathrm{a}}$ & $43(31)$ & $14(17)$ & $29(52)$ & $<0.0001$ \\
\hline Hematological malignancies & $13(9)$ & $3(4)$ & $10(18)$ & \\
\hline Solid tumor & $10(7)$ & $2(2)$ & $8(14)$ & \\
\hline Solid organ transplantation & $8(6)$ & $4(5)$ & $4(7)$ & \\
\hline High-dose or long-term CS/IS & $8(6)$ & $3(4)$ & $5(9)$ & \\
\hline Human immunodeficiency virus & $4(3)$ & $2(2)$ & $2(4)$ & \\
\hline ARDS etiology & & & & 0.01 \\
\hline Peri-/post-operative & $24(17)$ & $13(15)$ & $11(20)$ & \\
\hline $2009 \mathrm{~A}\left(\mathrm{H}_{1} \mathrm{~N}_{1}\right)$ influenza & $36(26)$ & $30(36)$ & $6(11)$ & \\
\hline Bacterial infection & $63(45)$ & $34(40)$ & $29(52)$ & \\
\hline Others & $17(12)$ & $7(8)$ & $10(18)$ & \\
\hline
\end{tabular}

Values are expressed as median (interquartile range) or $n(\%)$ $A R D S$ acute respiratory disease syndrome, $C S / I S$ corticosteroids or immunosuppressants, ECMO extracorporeal membrane oxygenation, ICU intensive care unit, SAPS simplified acute physiology score, SOFA sepsis-related organ failure assessment

Intensive care unit and 6-month outcomes

Complications during ECMO are listed in Table E1 (see ESM). Bleeding events occurred in $46 \%$ of patients. Respectively, 74 and $16 \%$ of patients developed ventilator-associated pneumonia and cannula infection. Renal replacement therapy was required by $56 \%$ of patients and $63 \%$ were tracheostomized. Ninety $(64 \%)$ patients survived to ICU discharge. In-ICU deaths were attributed to multiple organ failure for 28 , septic shock for 18 , hemorrhagic shock for 6 , intracranial bleeding for 4 and brainhypoxia sequelae for 4 . Respective median durations of ECMO and MV support were 15 (8-30) and 40 (23-68) days, and median hospital length of stay was 65 (39-111) days.

Six patients died 61 (20-76) days after ICU discharge (two had left the hospital before dying). Six months after ICU discharge, $84(60 \%)$ patients were still alive. The 36 patients with $\mathrm{A}\left(\mathrm{H}_{1} \mathrm{~N}_{1}\right)$-associated ARDS had the lowest reported mortality to date $(17 \%)$. Multivariable analysis (Table E2 [see ESM]; Table 3) retained older age, immunocompromised status, higher simplified acute physiology score (SAPS II) [calculated excluding the age component], higher pre-ECMO Pplat, lower pre-ECMO PEEP, absence of pre-ECMO prone positioning and the number of days on MV before ECMO as factors a Immunocompromised status included hematological malignancies, solid tumors, solid-organ transplantation, high-dose or longterm corticosteroid and/or immunosuppressant use, or human immunodeficiency virus infection

independently associated with death by 6 months while higher body mass index (BMI) was associated with lower mortality (see ESM for details). The PRESERVE score developed after transforming continuous into categorical variables (Table E3 [see ESM]) is displayed in Table 4. Cumulative probabilities of survival by 6 months following ECMO initiation were 97, 79, 54 and only $16 \%$ for PRESERVE score classes 0-2 $(n=34), 3-4$ $(n=38), 5-6(n=26)$ and $\geq 7(n=38)$, respectively (Fig. 2). ROC curve analysis of the performance of this scoring system (Figure E1) is shown in the ESM. The area under the curve was 0.89 (95\% CI 0.83-0.94).

Interestingly, patients retrieved by our mobile ECMO teams had lower unadjusted mortality than patients who received ECMO inhouse (34 vs. $53 \%, p=0.027$, respectively). However, retrieved patients had significantly less comorbidities and suffered $\mathrm{A}(\mathrm{H} 1 \mathrm{~N} 1)$ infection more frequently ( 33 vs. $13 \%, p=0.016$ ). After adjusting for other confounders, this variable was not associated with death at 6 months (Table 3).

\section{Long-term outcomes}

Long-term evaluation was conducted a median of 17 (11-28) months after ICU discharge, when three more 
Table 2 Ventilation characteristics at the time of ECMO initiation according to survival status

\begin{tabular}{|c|c|c|c|c|}
\hline \multirow[t]{2}{*}{ Characteristic } & \multirow[b]{2}{*}{$\begin{array}{l}\text { All patients } \\
(n=140)\end{array}$} & \multicolumn{2}{|c|}{ Status at 6 months post-ICU } & \multirow[t]{2}{*}{$p$-Value } \\
\hline & & $\begin{array}{l}\text { Alive } \\
(n=84)\end{array}$ & $\begin{array}{l}\text { Dead } \\
(n=56)\end{array}$ & \\
\hline \multicolumn{5}{|l|}{ Ventilation parameters } \\
\hline $\mathrm{PaO}_{2} / \mathrm{FiO}_{2}$ & $53(43-60)$ & $53(42-58)$ & $54(45-69)$ & 0.15 \\
\hline $\mathrm{FiO}_{2}$ & $100(100-100)$ & $100(100-100)$ & $100(100-100)$ & 0.76 \\
\hline $\mathrm{PEEP}, \mathrm{cm} \mathrm{H}_{2} \mathrm{O}$ & $10(8-12)$ & $10(9-12)$ & $8(8-10)$ & 0.001 \\
\hline Tidal volume, $\mathrm{mL} / \mathrm{kg}$ & $5.9(5.2-6.7)$ & $5.9(5.1-6.6)$ & $5.9(5.2-6.8)$ & 0.99 \\
\hline Respiratory rate, /min & $30(26-30)$ & $30(26-30)$ & $30(25-32)$ & 0.42 \\
\hline Plateau pressure, $\mathrm{cm} \mathrm{H}_{2} \mathrm{O}$ & $32(30-35)$ & $32(30-35)$ & $34(31-35)$ & 0.009 \\
\hline Driving pressure, $\mathrm{cm} \mathrm{H}_{2} \mathrm{O}$ & $22(19-27)$ & $21(18-24)$ & $24(22-28)$ & 0.0006 \\
\hline Compliance, $\mathrm{mL} / \mathrm{cm} \mathrm{H}_{2} \mathrm{O}$ & $18(14-21)$ & $19(15-21)$ & $16(12-20)$ & 0.04 \\
\hline \multicolumn{5}{|l|}{ Pre-ECMO blood gases } \\
\hline $\mathrm{pH}$ & $7.22(7.15-7.32)$ & $7.23(7.16-7.32)$ & $7.22(7.14-7.30)$ & 0.30 \\
\hline $\mathrm{PaO}_{2}, \mathrm{mmHg}$ & $53(44-58)$ & $52(42-55)$ & $53(45-68)$ & 0.11 \\
\hline $\mathrm{PaCO}_{2}, \mathrm{mmHg}$ & $63(51-77)$ & $60(50-70)$ & $70(53-80)$ & 0.02 \\
\hline $\mathrm{HCO}_{3}{ }^{-}, \mathrm{mmol} / \mathrm{L}$ & $27(23-32)$ & $26(23-30)$ & $27(23-34)$ & 0.19 \\
\hline $\mathrm{SaO}_{2}(\%)$ & $80(74-85)$ & $80(74-85)$ & $80(73-88)$ & 0.18 \\
\hline Arterial lactate, $\mathrm{mmol} / \mathrm{L}$ & $2.2(1.5-3.4)$ & $2.3(1.8-3.8)$ & $2.1(1.2-3.1)$ & 0.10 \\
\hline Quadrants with infiltrate, $n$ & $4(4-4)$ & $4(4-4)$ & $4(4-4)$ & 1 \\
\hline \multicolumn{5}{|l|}{ Rescue therapy } \\
\hline Any & $131(94)$ & $81(96)$ & $50(89)$ & 0.11 \\
\hline Prone positioning & $82(59)$ & $52(62)$ & $30(54)$ & 0.32 \\
\hline Nitric oxide & $127(91)$ & $77(92)$ & $50(89)$ & 0.63 \\
\hline Almitrine & $11(8)$ & 9 (11) & $2(4)$ & 0.12 \\
\hline HFOV & $1(1)$ & 0 & $1(2)$ & - \\
\hline Pre-ECMO steroids & $35(25)$ & $14(17)$ & $21(38)$ & 0.006 \\
\hline Vasopressors & $98(70)$ & $61(73)$ & $37(66)$ & 0.40 \\
\hline Pre-ECMO pneumothorax & $5(4)$ & $2(2)$ & $3(5)$ & 0.35 \\
\hline Mobile ECMO team & $95(68)$ & $63(75)$ & $32(57)$ & 0.03 \\
\hline \multicolumn{5}{|l|}{ Interval (days) } \\
\hline Hospital-ICU admission & $0(0-1)$ & $0(0-1)$ & $0.5(0-3)$ & 0.08 \\
\hline Hospital admission-ECMO & $7(3-14)$ & $5(2-11)$ & $13(7-27)$ & $<0.0001$ \\
\hline ICU admission-ECMO & $6(2-13)$ & $4(1-9)$ & $9(4-17)$ & $<0.0001$ \\
\hline MV-ECMO & $5(1-11)$ & $3(1-9)$ & $7(3-15)$ & 0.0008 \\
\hline
\end{tabular}

Values are expressed as median (interquartile range) or $n(\%)$

$E C M O$ extracorporeal membrane oxygenation, $H F O V$ high-frequency oscillation ventilation, $I C U$ intensive care unit, $M V$ mechanical ventilation, $P E E P$ positive end-expiratory pressure

patients had died. HRQL and psychosocial questionnaires were administered to $67(80 \%)$ of the 6-month survivors (Fig. 1). Among these 67 patients, 7 were retired, 3 were unemployed and 57 were working full-time before their critical illness. At follow-up, 41/57 (72\%) of the latter had returned to work (35/57 [52\%] to their previous work) and most reported normal functions (Table E1 [see $\mathrm{ESM}])$.

SF-36 assessment of HRQL is reported in Fig. 3. Compared with age- and sex-matched controls, our responding ARDS survivors had significantly lower $(p<0.001)$ SF-36 physical domain scores. Their psychological domain scores were comparable with those of the general population, with the exception of their roleemotional component, which was lower $(p<0.001)$. Their SF-36 physical aggregate scores were also significantly lower $(p<0.001)$, while their mental aggregate scores were comparable. Patients with longer follow-up (>503 days) had significantly improved role-physical $(p=0.001)$ and role-emotional $(p=0.049)$ domain scores (Table E4 [see ESM]). Patients whose ECMO support lasted longer tended to have lower bodily pain domain and aggregate physical scores (Table E5 [see ESM]).

During follow-up questioning, $24(36 \%)$ patients reported persistent dyspnea. In addition, 20 (30\%) patients were still taking pulmonary medications (longacting $\beta_{2}$-agonists for 16 patients, inhaled corticosteroids for 7, home oxygen therapy for 1 and nocturnal MV for 3 ). The SGRQ scores indicated that patients with longer ECMO support had more pulmonary symptoms (Table E5 [see ESM]).

Twenty-three (34\%), $17(25 \%)$ and $11(16 \%)$ of the respondents (Fig. 4), respectively, exhibited significant anxiety and depression symptoms or were at risk for PTSD. HAD and IES scores did not differ significantly for patients with longer versus shorter follow-up or those who had longer ECMO support (Tables E4 and E5 [see ESM]). 
Table 3 Factors available at ECMO institution independently associated with death by 6 months post-ICU discharge

\begin{tabular}{llr}
\hline Factor & OR $(95 \% \mathrm{CI})$ & $p$-Value \\
\hline Age & $1.08(1.04-1.12)$ & $<0.001$ \\
Body mass index $_{\text {Immunocompromised }}{ }^{\mathrm{a}}$ & $0.90(0.84-0.97)$ & 0.004 \\
SAPS II $^{\mathrm{b}}$ & $4.33(1.55-12.12)$ & 0.005 \\
Days of MV $_{\text {No prone positioning before ECMO }}$ & $1.04(1.00-1.08)$ & 0.028 \\
PEEP, cm $\mathrm{H}_{2} \mathrm{O}$ & $0.03(1.01-1.14)$ & 0.015 \\
Plateau pressure, cm $\mathrm{H}_{2} \mathrm{O}$ & $1.18(1.04-0.25)$ & 0.043 \\
\hline
\end{tabular}

$C I$ confidence interval, ECMO extracorporeal membrane oxygenation, $I C U$ intensive care unit, $M V$ mechanical ventilation, $O R$ odds ratio, PEEP positive end-expiratory pressure, SAPS II simplified acute physiology score

a Immunocompromised status included hematological malignancies, solid tumors, solid organ transplantation, high-dose or longterm corticosteroid and/or immunosuppressant use, or human immunodeficiency virus infection

b Age was not included in SAPS II calculation for multivariable analysis

Table 4 The PRESERVE score calculated with parameters available at the time of decision to initiate ECMO

\begin{tabular}{ll}
\hline Parameter & Score \\
\hline Age (years) & \\
$\quad<45$ & 0 \\
$45-55$ & 2 \\
$>55$ & 3 \\
Body mass index $>30$ & -2 \\
Immunocompromised & 2 \\
SOFA >12 & 1 \\
MV $>6$ days & 1 \\
No prone positioning before ECMO & 1 \\
PEEP $<10$ cm $\mathrm{H}_{2} \mathrm{O}$ & 2 \\
Plateau pressure $>30 \mathrm{~cm} \mathrm{H}_{2} \mathrm{O}$ & 2 \\
Total score & $0-14$ \\
\hline
\end{tabular}

ECMO extracorporeal membrane oxygenation, $I C U$ intensive care unit, $M V$ mechanical ventilation, $P E E P$ positive end-expiratory pressure, PRESERVE PRedicting dEath for SEvere ARDS on VVECMO, SAPS II simplified acute physiology score, SOFA sepsisrelated organ failure assessment

a Immunocompromised status included hematological malignancies, solid tumors, solid organ transplantation, high-dose or longterm corticosteroid and/or immunosuppressant use, or human immunodeficiency virus infection

b SOFA score was preferred over SAPS II (excluding the age component) for simpler use of the score at the bedside

${ }^{c}$ Higher score indicates higher probability of death by 6 months post-ICU discharge; PRESERVE scores -1 and -2 converted to 0 for simplification

\section{Discussion}

To our knowledge, this is the largest $(n=140)$, comprehensive, multicenter, follow-up study on ECMO-treated severe ARDS patients. Despite very severe disease at ECMO initiation, the $40 \%$ 6-month mortality we observed for this series is lower than the $50 \%$ hospital mortality rate recently reported in the Oscillation in ARDS (OSCAR) trial (where mean $\mathrm{PaO}_{2} / \mathrm{FiO}_{2}$ was $113 \mathrm{mmHg}$ at randomization) [42]. It is also lower than those reported in previous series of ECMO-treated ARDS patients [15, 43, 44], and comparable with that of the ECMO arm of the CESAR trial [9], in which initial $\mathrm{PaO}_{2} / \mathrm{FiO}_{2}$ was higher (76 vs. $53 \mathrm{mmHg})$. Interestingly, $\mathrm{A}\left(\mathrm{H}_{1} \mathrm{~N}_{1}\right)$-induced ARDS patients included in this study had the lowest mortality rate (17\%) reported to date [12-14, 45].

The first objective of this study was to identify preECMO outcome predictors to help ICU physicians select, for ECMO support, very severe ARDS patients with reasonable chance of survival. The PRESERVE scoring system we propose herein, which combines eight simple variables easily available at the time of ECMO decision, identified four subgroups of patients with significantly different probabilities of survival (Fig. 3). Age, immunocompromised status, and pre-ECMO Pplat $>30 \mathrm{~cm}$ $\mathrm{H}_{2} \mathrm{O}$ and PEEP $<10 \mathrm{~cm} \mathrm{H}_{2} \mathrm{O}$ (despite optimization of $\mathrm{MV}$ settings according to the recommendations based on the ARDSnet studies [18]) had the highest impact on the outcomes of our patients. As opposed to previous studies [15], pre-ECMO $\mathrm{PaO}_{2} / \mathrm{FiO}_{2}$ was not associated with survival after adjusting for the latter parameters, suggesting that alterations in lung mechanics are more important prognostic factors than severity of hypoxemia. Furthermore, because a recent study indicated major survival improvement with early prone positioning of ARDS patients [40], we forced this parameter into our multivariable model and observed that it was independently associated with lower mortality. Interestingly, prone-positioned patients had significantly higher PEEP and lower Pplat and driving pressures before ECMO (data not shown). While prone placement did not prevent refractory hypoxemia leading to ECMO in nearly twothirds of our severe ARDS patients (the highest rate in the ECMO series reported to date), it might have protected their lungs from further MV-induced lung injuries and ultimately resulted in better long-term survival. Our study also confirmed that pre-ECMO MV for more than 1 week was associated with lower survival $[15,16]$. In severely hypoxemic patients with profound alteration in lung mechanics and not, or only partially, responding to prone placement, ECMO might therefore be discussed very early in the course of the disease. Notably, BMI $>30 \mathrm{~kg} /$ $\mathrm{m}^{2}$ was associated with better outcomes, independently of pre-ECMO Pplat and PEEP. Although it has frequently been reported that obese patients have better ICU outcomes than normal-weight patients [46], this observation might suggest that Pplat might not be a valid surrogate of transpulmonary pressure in obese patients and, therefore, might not necessarily mean more severe respiratory failure, because their chest wall elastance is higher than normal reference values.

HRQL evaluated after a median follow-up of 17 months for $80 \%$ of the 6-month ICU survivors was 
Fig. 2 Kaplan-Meier estimates of cumulative probabilities of survival for patients with preECMO PRESERVE score classes 0-3 $(n=34), 4-6$ $(n=38), 7-9(n=31)$ and $10-15(n=32)$. The $p$-value was calculated by means of the log-rank test. ECMO extracorporeal membrane oxygenation, PRESERVE PRedicting dEath for SEvere ARDS on VV-ECMO
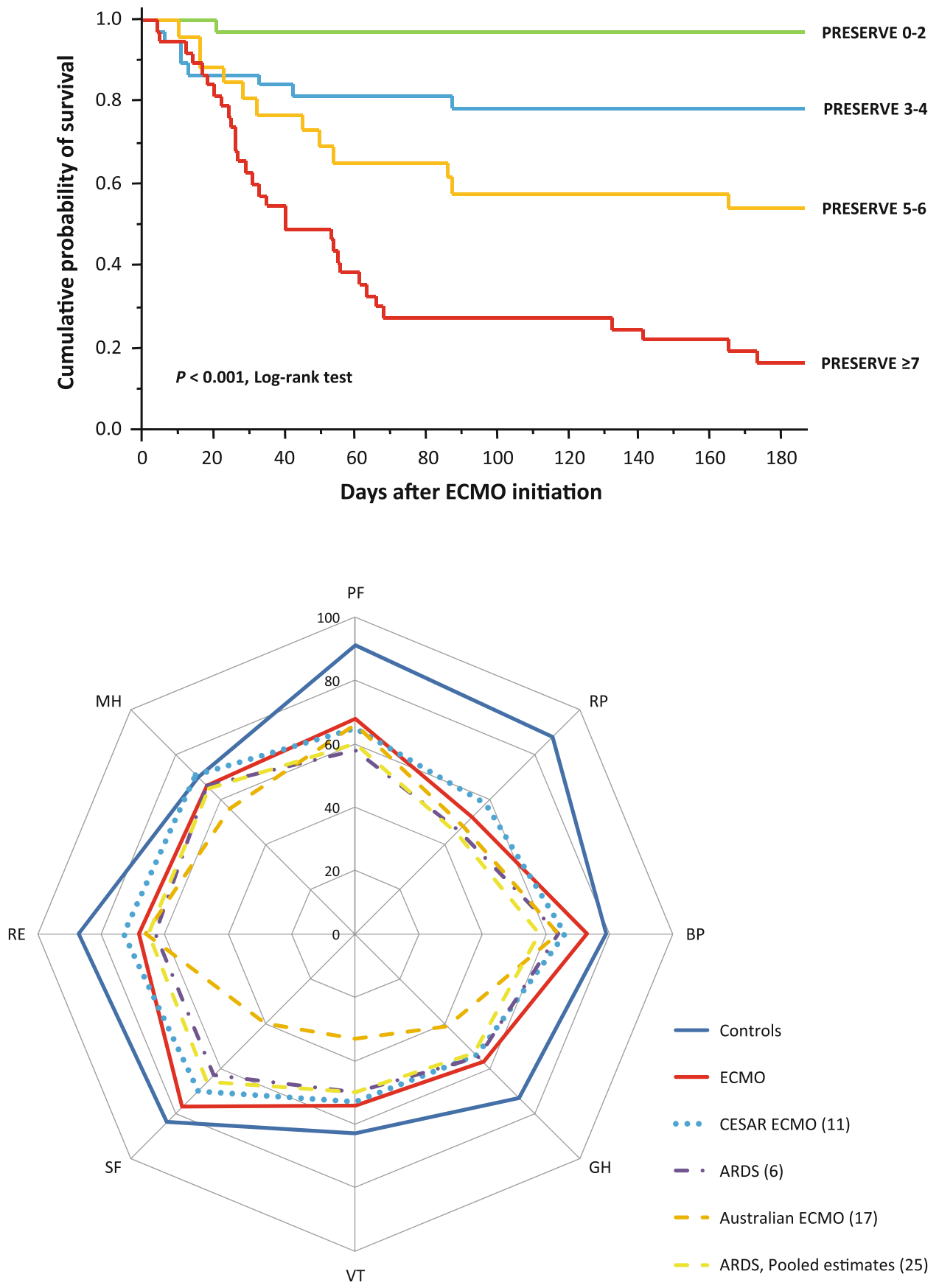

Fig. 3 Comparison of median SF36 scores of 67 of our ARDS survivors treated by ECMO after a median follow-up of 17 months after intensive care unit discharge and their 67 age- and sex-matched control subjects [27], and 80 conventionally treated ARDS survivors at 1 -year of follow-up [4], 57 ECMO-arm ARDS patients included in the conventional ventilation or ECMO for severe adult respiratory failure (CESAR) trial [9], 15 ECMO-treated Australian patients with refractory hypoxemia [19] and a pooled estimated score of five follow-up studies on ARDS survivors [33]. Higher scores denote better health-related quality of life. $A R D S$ acute respiratory distress syndrome, $B P$ body pain, $E C M O$ extracorporeal membrane oxygenation, $G H$ general health, $M H$ mental health, $P F$ physical functioning, $R E$ role-emotional, $R P$ role-physical, $S F$ social functioning, $S F-36$ Short Form$36, V T$ vitality still impaired compared with that of sex- and age-matched controls, especially concerning SF-36 physical health and vitality domains, while social functioning and mental health were considered satisfactory. Although differences in case-mixes make comparisons between series difficult, we observed that our patients' SF-36 scores were better (Fig. 3) than those of eighty 1-year ARDS survivors evaluated by Herridge et al. [4], or a pooled estimated SF36 score based on five ARDS-survivor cohorts [33]. In agreement with Herridge et al. [4, 5], we also found that physical and emotional domains improved with longer follow-up. Data on long-term HRQL of ECMO-treated ARDS patients are scarce. Although the 57 ECMO-arm survivors included in the CESAR trial [9] and 15 ECMOtreated $\mathrm{A}\left(\mathrm{H}_{1} \mathrm{~N}_{1}\right)$-induced ARDS patients from the French réseaux européen de recherche en ventilation artificielle (REVA) cohort [21] had SF-36 scores comparable with those of our patients (Fig. 3), a recent study on 15 Australian ARDS survivors [19] reported lower social function, vitality and general health-domain scores. 

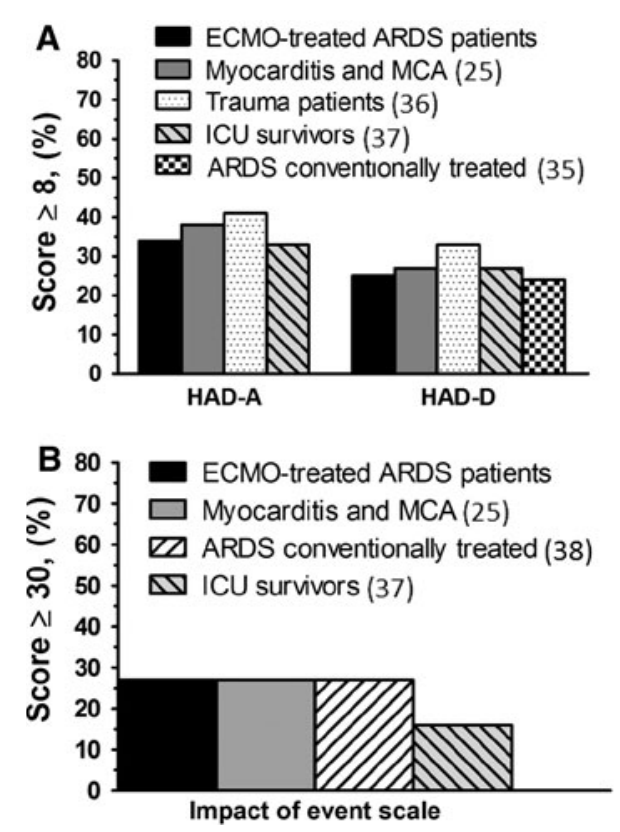

Fig. 4 a Mean percentages of our ARDS survivors treated by ECMO (evaluated after a median follow-up of 17 months after ICU discharge) with clinically significant anxiety and/or depression (HAD-A/D subscale scores $\geq 8 / 21$ ) compared with those of 156 conventionally treated ARDS patients [35], 26 myocarditis survivors treated by MCA [25], 153 trauma patients [36] and 194 ICU survivors [37]. b Mean percentages of our ECMO-treated ARDS survivors at risk of post-traumatic stress disorder compared with those of 80 conventionally treated ARDS patients [38], 26 myocarditis survivors [25] and 194 ICU survivors [37]. ARDS acute respiratory distress syndrome, ECMO extracorporeal membrane oxygenation, $H A D$ Hospital Anxiety and Depression, ICU intensive care unit, $M C A$ mechanical circulatory assistance

Notably, less than half of those Australian patients had returned to work, compared with $72 \%$ of our patients.

Regular episodes of dyspnea were reported herein by $36 \%$ of the respondents, and SGRQ scores revealed a perception of physical limitations comparable with that reported in previous ARDS series with different casemixes [3, 6, 9, 20, 34, 39] (Fig. E2 [see ESM]). ARDS survivors frequently complain of subjective symptoms such as 'shortness of breath' even during light exercise, despite minor residual abnormalities on pulmonary computed tomography scan $[21,47]$. ICU-acquired diaphragmatic dysfunction and respiratory muscle weakness may therefore contribute to the persistence of these symptoms despite improvement in pulmonary function. Future studies should now focus on the pathophysiology of musculoskeletal sequelae of critical illnesses, and establishment of customized, patient-centered, rehabilitation programs that might help improve long-term outcomes.

The burden of ARDS-induced psychological sequelae in our ECMO-treated patients was still perceptible
17 months post-ICU discharge. Notably, 34 and $25 \%$ reported symptoms of severe anxiety and/or depression, and $15 \%$ were at risk of PTSD. Although they were more severely ill during the acute disease phase, their probabilities of anxiety, depression and/or PTSD were similar to those reported in other post-ICU studies [25, 35-37, 48, 49] (Fig. 3a, b). Identification of anxious and/or depressive patients and those at risk of developing PTSD might allow prescription of specific medications and cognitive and/or behavioral strategies to control their emotional and psychological distress.

Our study's strengths are the large number of patients included, detailed characterization of the population considered, and its multicenter and longitudinal design, with high rates of follow-up 17 months after ICU discharge. However, our study also has limitations. First, since it was not possible to measure HRQL before disease onset, the lower HRQL observed could be attributable to pre-existing health conditions and not directly related to severe ARDS and/or ECMO. Second, the self-assessed, persistently impaired physical health and vitality might not be specific to ARDS but may represent sequelae of any severe disease requiring prolonged ICU stay, including critical illness, muscle-wasting and weakness. Third, Papazian et al. [50] demonstrated that $48 \mathrm{~h}$ of intravenous cisatracurium besylate significantly improved outcomes of ARDS patients. However, prescription of neuromuscular blocking agents was not recorded in our database and therefore this variable was not tested into our multivariable models. Lastly, the PRESERVE score should now be tested in other populations of severe ARDS patients receiving ECMO since its performance might be overestimated if only based on the analysis of our cohort of patients.

In conclusion, long-term survival of this multicenter cohort of 140 ECMO-treated patients with refractory ARDS reached $60 \%$. HRQL evaluation in $80 \%$ of the 6-month survivors revealed persistent physical and emotional-related difficulties, with anxiety, depression or PTSD symptoms reported by 34,25 or $16 \%$, respectively. The PRESERVE score we developed might help ICU physicians select appropriate candidates for ECMO among severe ARDS patients. However, before widespread utilization, this scoring system should now be tested in other groups of ECMO-treated severe ARDS patients with different case-mixes. Ongoing randomized studies might also help better define indications of ECMO for severe ARDS patients [22].

Conflicts of interest Professor Combes is the primary investigator of the ECMO to rescue lung injury in severe ARDS (EOLIA) trial, NCT01470703, a randomized trial of VV-ECMO supported in part by MAQUET. He has received honoraria for lectures by MAQUET. All other authors have no conflicts of interest to declare. 


\section{References}

1. Sud S, Friedrich JO, Taccone P, Polli F, Adhikari NK, Latini R, Pesenti A, Guerin C, Mancebo J, Curley MA, Fernandez R, Chan MC, Beuret P, Voggenreiter G, Sud M, Tognoni G, Gattinoni L (2010) Prone ventilation reduces mortality in patients with acute respiratory failure and severe hypoxemia: systematic review and metaanalysis. Intensive Care Med 36:585-599

2. Adhikari NK, McAndrews MP, Tansey CM, Matte A, Pinto R, Cheung AM, Diaz-Granados N, Barr A, Herridge MS (2009) Self-reported symptoms of depression and memory dysfunction in survivors of ARDS. Chest 135:678-687

3. Davidson TA, Caldwell ES, Curtis JR, Hudson LD, Steinberg KP (1999) Reduced quality of life in survivors of acute respiratory distress syndrome compared with critically ill control patients. JAMA 281:354-360

4. Herridge MS, Cheung AM, Tansey CM, Matte-Martyn A, Diaz-Granados N, AlSaidi F, Cooper AB, Guest CB, Mazer CD, Mehta S, Stewart TE, Barr A, Cook D, Slutsky AS (2003) One-year outcomes in survivors of the acute respiratory distress syndrome. N Engl J Med 348:683-693

5. Herridge MS, Tansey CM, Matte A, Tomlinson G, Diaz-Granados N, Cooper A, Guest CB, Mazer CD, Mehta S, Stewart TE, Kudlow P, Cook D, Slutsky AS, Cheung AM (2011) Functional disability 5 years after acute respiratory distress syndrome. $\mathrm{N}$ Engl J Med 364:1293-1304

6. Heyland DK, Groll D, Caeser M (2005) Survivors of acute respiratory distress syndrome: relationship between pulmonary dysfunction and long-term health-related quality of life. Crit Care Med 33:1549-1556

7. Combes A, Bacchetta M, Brodie D, Muller T, Pellegrino V (2012)

Extracorporeal membrane oxygenation for respiratory failure in adults. Curr Opin Crit Care 18:99-104

8. MacLaren G, Combes A, Bartlett RH (2012) Contemporary extracorporeal membrane oxygenation for adult respiratory failure: life support in the new era. Intensive Care Med 38:210-220

9. Peek GJ, Mugford M, Tiruvoipati R, Wilson A, Allen E, Thalanany MM, Hibbert CL, Truesdale A, Clemens F, Cooper N, Firmin RK, Elbourne D (2009) Efficacy and economic assessment of conventional ventilatory support versus extracorporeal membrane oxygenation for severe adult respiratory failure (CESAR): a multicentre randomised controlled trial. Lancet 374:1351-1363
10. Brodie D, Bacchetta M (2012) Extracorporeal membrane oxygenation for ARDS in adults. N Engl J Med 365:1905-1914

11. Combes A, Brechot N, Luyt CE, Schmidt M (2012) What is the niche for extracorporeal membrane oxygenation in severe acute respiratory distress syndrome? Curr Opin Crit Care 18:527-532

12. Pham T, Combes A, Roze H, Chevret S, Mercat A, Roch A, Mourvillier B, AraSomohano C, Bastien O, Zogheib E, Clavel M, Constan A, Marie Richard JC, Brun-Buisson C, Brochard L (2013) Extracorporeal membrane oxygenation for pandemic influenza $\mathrm{A}(\mathrm{H} 1 \mathrm{~N} 1)-$ induced acute respiratory distress syndrome: a Cohort study and propensity-matched analysis. Am J Respir Crit Care Med 187:276-285

13. Noah MA, Peek GJ, Finney SJ, Griffiths MJ, Harrison DA, Grieve R, Sadique MZ, Sekhon JS, McAuley DF, Firmin RK, Harvey C, Cordingley JJ, Price S, Vuylsteke A, Jenkins DP, Noble DW, Bloomfield R, Walsh TS, Perkins GD, Menon D, Taylor BL, Rowan KM (2011) Referral to an extracorporeal membrane oxygenation center and mortality among patients with severe 2009 influenza $\mathrm{A}(\mathrm{H} 1 \mathrm{~N} 1)$. JAMA 306:1659-1668

14. Davies A, Jones D, Bailey M, Beca J, Bellomo R, Blackwell N, Forrest P, Gattas D, Granger E, Herkes R, Jackson A, McGuinness S, Nair P, Pellegrino V, Pettila V, Plunkett B, Pye R, Torzillo P, Webb S, Wilson M, Ziegenfuss M (2009) Extracorporeal membrane oxygenation for 2009 influenza $\mathrm{A}(\mathrm{H} 1 \mathrm{~N} 1)$ acute respiratory distress syndrome. JAMA 302:1888-1895

15. Hemmila MR, Rowe SA, Boules TN, Miskulin J, McGillicuddy JW, Schuerer DJ, Haft JW, Swaniker F, Arbabi S, Hirschl RB, Bartlett RH (2004) Extracorporeal life support for severe acute respiratory distress syndrome in adults. Ann Surg 240:595-605 discussion 605-597

16. Brogan TV, Thiagarajan RR, Rycus PT, Bartlett RH, Bratton SL (2009) Extracorporeal membrane oxygenation in adults with severe respiratory failure: a multi-center database. Intensive Care Med 35:2105-2114
17. Guerin C, Reignier J, Richard JC, Beuret P, Gacouin A, Boulain T, Mercier E, Badet M, Mercat A, Baudin O, Clavel M, Chatellier D, Jaber S, Rosselli S, Mancebo J, Sirodot M, Hilbert G, Bengler C, Richecoeur J, Gainnier M, Bayle F, Bourdin G, Leray V, Girard R, Baboi L, Ayzac L (2013) Prone positioning in severe acute respiratory distress syndrome. N Engl J Med 368:2159-2168

18. (2000) Acute respiratory distress syndrome network. Ventilation with lower tidal volumes as compared with traditional tidal volumes for acute lung injury and the acute respiratory distress syndrome. N Engl J Med 342:1301-1308

19. Hodgson CL, Hayes K, Everard T, Nichol A, Davies AR, Bailey MJ, Tuxen DV, Cooper DJ, Pellegrino V (2012) Long-term quality of life in patients with acute respiratory distress syndrome requiring extracorporeal membrane oxygenation for refractory hypoxaemia. Crit Care 16:R202

20. Linden VB, Lidegran MK, Frisen G, Dahlgren P, Frenckner BP, Larsen F (2009) ECMO in ARDS: a long-term follow-up study regarding pulmonary morphology and function and healthrelated quality of life. Acta Anaesthesiol Scand 53:489-495

21. Luyt CE, Combes A, Becquemin MH, Beigelman-Aubry C, Hatem S, Brun AL, Zraik N, Carrat F, Grenier PA, Richard JC, Mercat A, Brochard L, Brun-Buisson C, Chastre J (2012) Long-term outcomes of pandemic 2009 influenza $\mathrm{A}(\mathrm{H} 1 \mathrm{~N} 1)$-associated severe ARDS. Chest 142:583-592

22. EOLIA trial, Accessed May 15th, 2013. http://wwwclinicaltrialsgov/ct2/show/ NCT01470703?term=eolia\&rank=1

23. Schmidt M, Tachon G, Devilliers C, Muller G, Hekimian G, Brechot N, Merceron S, Luyt CE, Trouillet JL, Chastre J, Leprince P, Combes A (2013) Blood oxygenation and decarboxylation determinants during venovenous ECMO for respiratory failure in adults. Intensive Care Med 39:838-846

24. Schmidt M, Brechot N, Hariri S, Guiguet M, Luyt CE, Makri R, Leprince P, Trouillet JL, Pavie A, Chastre J, Combes A (2012) Nosocomial infections in adult cardiogenic shock patients supported by venoarterial extracorporeal membrane oxygenation. Clin Infect Dis 55:1633-1641 
25. Mirabel M, Luyt CE, Leprince P, Trouillet JL, Leger P, Pavie A, Chastre J, Combes A (2011) Outcomes, longterm quality of life, and psychologic assessment of fulminant myocarditis patients rescued by mechanical circulatory support. Crit Care Med 39:1029-1035

26. Trouillet JL, Luyt CE, Guiguet M, Ouattara A, Vaissier E, Makri R, Nieszkowska A, Leprince P, Pavie A, Chastre J, Combes A (2011) Early percutaneous tracheotomy versus prolonged intubation of mechanically ventilated patients after cardiac surgery: a randomized trial. Ann Intern Med 154:373-383

27. Leplege A, Ecosse E, Verdier A, Perneger TV (1998) The French SF-36 Health Survey: translation, cultural adaptation and preliminary psychometric evaluation. J Clin Epidemiol 51:1013-1023

28. Jones PW, Quirk FH, Baveystock CM (1991) The St George's Respiratory Questionnaire. Respiratory medicine 85(Suppl B):25-31 discussion 33-27

29. Zigmond AS, Snaith RP (1983) The hospital anxiety and depression scale. Acta Psychiatr Scand 67:361-370

30. Horowitz M, Wilner N, Alvarez W (1979) Impact of Event Scale: a measure of subjective stress. Psychosom Med 41:209-218

31. Katz S, Ford AB, Moskowitz RW, Jackson BA, Jaffe MW (1963) Studies of illness in the aged: the index of ADL: a standardized measure of biological and psychosocial function. JAMA 185:914-919

32. Lawton MP, Brody EM (1969) Assessment of older people: selfmaintaining and instrumental activities of daily living. Gerontologist 9:179-186

33. Dowdy DW, Eid MP, Dennison CR, Mendez-Tellez PA, Herridge MS, Guallar E, Pronovost PJ, Needham DM (2006) Quality of life after acute respiratory distress syndrome: a metaanalysis. Intensive Care Med 32:1115-1124

34. Tansey CM, Louie M, Loeb M, Gold WL, Muller MP, de Jager J, Cameron JI, Tomlinson G, Mazzulli T, Walmsley SL, Rachlis AR, Mederski BD, Silverman M, Shainhouse Z, Ephtimios IE, Avendano M, Downey J, Styra R, Yamamura D, Gerson M, Stanbrook MB, Marras TK, Phillips EJ, Zamel N, Richardson SE, Slutsky AS, Herridge MS (2007) One-year outcomes and health care utilization in survivors of severe acute respiratory syndrome. Arch Intern Med 167:1312-1320
35. Bienvenu OJ, Colantuoni E, MendezTellez PA, Dinglas VD, Shanholtz C, Husain N, Dennison CR, Herridge MS, Pronovost PJ, Needham DM (2012) Depressive symptoms and impaired physical function after acute lung injury: a 2-year longitudinal study. Am J Respir Crit Care Med 185:517-524

36. Ringdal M, Plos K, Ortenwall P, Bergbom I (2010) Memories and health-related quality of life after intensive care: a follow-up study. Crit Care Med 38:38-44

37. Myhren H, Ekeberg O, Stokland O (2010) Health-related quality of life and return to work after critical illness in general intensive care unit patients: a 1-year follow-up study. Crit Care Med 38:1554-1561

38. Schelling G, Stoll C, Haller M, Briegel J, Manert W, Hummel T, Lenhart A, Heyduck M, Polasek J, Meier M, Preuss U, Bullinger M, Schuffel W, Peter K (1998) Health-related quality of life and posttraumatic stress disorder in survivors of the acute respiratory distress syndrome. Crit Care Med 26:651-659

39. Combes A, Costa MA, Trouillet JL, Baudot J, Mokhtari M, Gibert C, Chastre J (2003) Morbidity, mortality, and quality-of-life outcomes of patients requiring $>$ or $=14$ days of mechanical ventilation. Crit Care Med 31:1373-1381

40. Drakos SG, Charitos CE, Ntalianis A, Terrovitis JV, Siafakas KX, Dolou P, Pierrakos C, Charitos E, Karelas J, Nanas JN (2005) Comparison of pulsatile with nonpulsatile mechanical support in a porcine model of profound cardiogenic shock. ASAIO J 51:26-29

41. Brechot N, Luyt CE, Schmidt M, Leprince P, Trouillet JL, Leger P, Pavie A, Chastre J, Combes A (2013) Venoarterial extracorporeal membrane oxygenation support for refractory cardiovascular dysfunction during severe bacterial septic shock. Crit Care Med 41:1616-1626

42. Young D, Lamb SE, Shah S, MacKenzie I, Tunnicliffe W, Lall R, Rowan K, Cuthbertson BH (2013) High-frequency oscillation for acute respiratory distress syndrome. N Engl J Med 368:806-813

43. Muller T, Philipp A, Luchner A, Karagiannidis C, Bein T, Hilker M, Rupprecht L, Langgartner J, Zimmermann M, Arlt M, Wenger J, Schmid C, Riegger GA, Pfeifer M, Lubnow M (2009) A new miniaturized system for extracorporeal membrane oxygenation in adult respiratory failure. Crit Care 13:R205
44. Beiderlinden M, Eikermann M, Boes T, Breitfeld C, Peters J (2006) Treatment of severe acute respiratory distress syndrome: role of extracorporeal gas exchange. Intensive Care Med 32:1627-1631

45. Patroniti N, Zangrillo A, Pappalardo F, Peris A, Cianchi G, Braschi A, Iotti GA, Arcadipane A, Panarello G, Ranieri VM, Terragni P, Antonelli M, Gattinoni L, Oleari F, Pesenti A (2011) The Italian ECMO network experience during the 2009 influenza $\mathrm{A}(\mathrm{H} 1 \mathrm{~N} 1)$ pandemic: preparation for severe respiratory emergency outbreaks. Intensive Care Med 37:1447-1457

46. Abhyankar S, Leishear K, Callaghan FM, Demner-Fushman D, McDonald CJ (2012) Lower short- and long-term mortality associated with overweight and obesity in a large cohort study of adult intensive care unit patients. Crit Care 16:R235

47. Wilcox ME, Herridge MS (2011) Lung function and quality of life in survivors of the acute respiratory distress syndrome (ARDS). Presse Med 40:e595-e603

48. Eddleston JM, White P, Guthrie E (2000) Survival, morbidity, and quality of life after discharge from intensive care. Crit Care Med 28:2293-2299

49. Jones C, Griffiths RD, Humphris G, Skirrow PM (2001) Memory, delusions, and the development of acute posttraumatic stress disorder-related symptoms after intensive care. Crit Care Med 29:573-580

50. Papazian L, Forel JM, Gacouin A, Penot-Ragon C, Perrin G, Loundou A, Jaber S, Arnal JM, Perez D, Seghboyan JM, Constantin JM, Courant P, Lefrant JY, Guerin C, Prat G, Morange S, Roch A (2010) Neuromuscular blockers in early acute respiratory distress syndrome. N Engl J Med 363:1107-1116 